\title{
A review of the direct and indirect effects of neonicotinoids and fipronil on vertebrate wildlife
}

\author{
David Gibbons • Christy Morrissey • Pierre Mineau
}

Received: 7 April 2014 / Accepted: 6 June 2014 / Published online: 18 June 2014

(C) The Author(s) 2014. This article is published with open access at Springerlink.com

\begin{abstract}
Concerns over the role of pesticides affecting vertebrate wildlife populations have recently focussed on systemic products which exert broad-spectrum toxicity. Given that the neonicotinoids have become the fastest-growing class of insecticides globally, we review here 150 studies of their direct (toxic) and indirect (e.g. food chain) effects on vertebrate wildlife - mammals, birds, fish, amphibians and reptiles. We focus on two neonicotinoids, imidacloprid and clothianidin, and a third insecticide, fipronil, which also acts in the same systemic manner. Imidacloprid and fipronil were found to be toxic to many birds and most fish, respectively. All three insecticides exert sub-lethal effects, ranging from genotoxic and cytotoxic effects, and impaired immune function, to reduced growth and reproductive success, often at concentrations well below those associated with mortality. Use of imidacloprid and clothianidin as seed treatments on some crops poses risks to small birds, and ingestion of even a few treated seeds could cause mortality or reproductive impairment to sensitive bird species. In contrast, environmental concentrations of imidacloprid and clothianidin appear to be
\end{abstract}

Responsible editor: Philippe Garrigues

D. Gibbons $(\bowtie)$

RSPB Centre for Conservation Science, RSPB, The Lodge, Sandy, Bedfordshire SG19 2DL, UK

e-mail: david.gibbons@rspb.org.uk

C. Morrissey

Department of Biology, University of Saskatchewan, 112 Science

Place, Saskatoon, Saskatchewan S7N 5E2, Canada

C. Morrissey

School of Environment and Sustainability, University of

Saskatchewan, 117 Science Place, Saskatoon, Saskatchewan S7N

$5 \mathrm{E} 2$, Canada

P. Mineau

Pierre Mineau Consulting, 124 Creekside Drive, Salt Spring

Island V8K 2E4, Canada at levels below those which will cause mortality to freshwater vertebrates, although sub-lethal effects may occur. Some recorded environmental concentrations of fipronil, however, may be sufficiently high to harm fish. Indirect effects are rarely considered in risk assessment processes and there is a paucity of data, despite the potential to exert population-level effects. Our research revealed two field case studies of indirect effects. In one, reductions in invertebrate prey from both imidacloprid and fipronil uses led to impaired growth in a fish species, and in another, reductions in populations in two lizard species were linked to effects of fipronil on termite prey. Evidence presented here suggests that the systemic insecticides, neonicotinoids and fipronil, are capable of exerting direct and indirect effects on terrestrial and aquatic vertebrate wildlife, thus warranting further review of their environmental safety.

Keywords Pesticide $\cdot$ Neonicotinoid · Imidacloprid · Clothianidin · Fipronil · Vertebrate · Wildlife · Mammals · Birds $\cdot$ Fish $\cdot$ Amphibians $\cdot$ Reptiles $\cdot$ Risk assessment

\section{Overview of impacts of pesticides on vertebrate wildlife}

Although vertebrates are the intended target of only $2 \%$ of pesticides on the market, the unintentional impacts of pesticides on vertebrate populations have been marked and are well documented (e.g. Sánchez-Bayo 2011). Pesticides can exert their impact on vertebrates either directly, through their toxicity, or indirectly, for example, by reducing their food supply.

Direct effects may be the result of several different exposure pathways: through ingestion of the formulated product (e.g. birds eating seeds coated with insecticide; Avery et al. 1997; Prosser and Hart 2005), through uptake via the skin following a spray event (Mineau 2011) or by eating 
contaminated prey. Probably the most notable example among the latter exposure pathway was the dramatic impact that organochlorine pesticides, especially DDT and its metabolite DDE, had on populations of birds of prey (Ratcliffe 1967; Newton 1995). Depending on the extent of intoxication, direct effects of pesticides can either kill vertebrates outright or exert sub-lethal effects, for example, on growth and reproduction (Sánchez-Bayo 2011). Progress since the organo-chlorine era has helped ensure that compounds that are currently being developed and registered are generally less persistent and do not as readily bio-accumulate in food webs.

More recently, however, interest has turned to investigating the potential for indirect effects which are typically mediated through loss in quantity or quality of prey associated with pesticide use, or through habitat modification (Sotherton and Holland 2002; Boatman et al. 2004; Morris et al. 2005). This is especially the case in jurisdictions where the use of highly toxic pesticides has been controlled and the frequency of direct impacts reduced (Mineau et al. 1999).

Over the last 2 decades, a new class of insecticides, the neonicotinoids, has become the most important and fastest growing of the five major chemical classes of insecticides on the global market (Jeschke and Nauen 2008; Jeschke et al. 2011; Tomizawa and Casida 2011; Casida and Durkin 2013). When used as plant protection products, neonicotinoids act by becoming distributed systemically throughout the growing plant following seed or soil applications. Another recent insecticide, fipronil, a phenyl-pyrazole (fiprole) rather than a neonicotinoid, also acts in the same manner and has a similar toxicity and persistence profile (Grant et al. 1998). Consequently, the neonicotinoids and fipronil are sometimes jointly termed 'systemic insecticides', although there are also older products which could be termed 'systemic', for example, the organo-phosphorous insecticide acephate and the organoarsenical, monosodium methanearsonate. Neonicotinoids are, in particular, commonly applied as seed treatments. The use of seed treatments as a convenient and effective application method has widespread appeal in the farming industry. Consequently, systemic seed treatments are now used on the majority of agricultural crops worldwide (Garthwaite et al. 2003; Jeschke et al. 2011).

Here, we build on the reviews of others (e.g. Goulson 2013; Köhler and Triebskorn 2013; Mineau and Palmer 2013) to examine the evidence and potential for direct and indirect effects of two common systemic neonicotinoid insecticides, imidacloprid and clothianidin, along with fipronil on vertebrate wildlife.

\section{Mode of action of the systemic insecticides}

Neonicotinoids work by interfering with neural transmission in the central nervous system. They bind to the nicotinic acetylcholine receptors ( $n \mathrm{AChR})$ in the postsynaptic neuron, acting as 'false neurotransmitters' (agonists). This interference with acetylcholine neurotransmitter signalling causes continuous activation of the receptor, leading to symptoms of neurotoxicity. Neonicotinoids have greater affinity for, and thus bind more strongly to, insect than mammalian or other vertebrate receptors, so their toxicity to mammals is lower than it is to insects and the reversibility of intoxication higher (Tomizawa and Casida 2005; Jeschke et al. 2011). Fipronil works similarly, but instead binds to the gamma-aminobutyric acid (GABA) receptors, resulting in similar continuous central nervous system activity (Tingle et al. 2000, 2003). As with neonicotinoids, fipronil has a lower affinity to vertebrate than to invertebrate receptors (Grant et al. 1998). Despite the lower toxicity of these products to vertebrates than to invertebrates, there is still ample evidence that vertebrates show toxic effects, albeit at markedly higher concentrations than for many target and non-target invertebrate species (e.g. Tingle et al. 2000, 2003; Cox 2001; SERA 2005; DeCant and Barrett 2010; Mineau and Palmer 2013).

\section{Materials and methods}

To assess the likely impacts of neonicotinoids and fipronil on vertebrates, a literature search was undertaken using Web of Science and Google Scholar. Search terms were [product] and [taxon], where [product] was either neonicotinoid, imidacloprid, thiacloprid, clothianidin, thiamethoxam, acetamiprid, nitenpyram, dinotefuran or fipronil; and [taxon] was either vertebrate*, mammal*, bird*, reptile*, amphibian* and fish*. In addition, specific searches were made on a few common toxicity test species (e.g. rat) and by following up references cited in the publications found by the search. The review also draws heavily on the recently published report by Mineau and Palmer (2013) on the direct and indirect toxicity of neonicotinoids to birds. Several industry studies, which have not been formally published but which were part of product approval processes, were reviewed by Mineau and Palmer and have been included here. While industry studies have been reviewed by regulators and may receive as much critical review as in the open peer-reviewed literature, emphasis here is on published reports and the primary literature.

The following information was extracted from each study: the product used, its dose and whether or not it was presented as a single dose (acute) or over a period of time (chronic; e.g. over 30 days); the effects on individual organisms, specifically whether there was an impact on survival, reproduction, growth and development, or other sub-lethal effects, such as neurobehavioural, genotoxic, cytotoxic, and immunotoxic; the impact on populations of the animal (e.g. local populations); the type of study, separated into laboratory or field; and finally whether it was a study of direct toxic effects, or indirect 
effects (e.g. leading to changes in food availability). In some cases, individual studies covered more than one species, and each is treated here as a separate species impact study.

The great majority of the studies were laboratory-based $(139 / 152=91 \%)$ and most $(146,96 \%)$ were direct toxicity studies. While common in ecotoxicology, the lack of field testing and over-reliance on laboratory direct toxicity testing limit our ability to interpret the findings under field-realistic conditions. Field experiments have provided some of the most compelling evidence of the impact of neonicotinoids on populations in their natural environment (e.g. Whitehorn et al. 2012), and there is an increasing recognition that maintaining ecological complexity in field studies is desirable (Suryanarayanan 2013).

The most common study taxa were mammals (58), birds (47) and fish (32), with substantially fewer studies of amphibians (12) and reptiles (3). Within these individual taxa, the most commonly studied mammals were rat, Rattus norvegicus, (39) and mouse, Mus musculus, (9); the most commonly studied birds were northern bobwhite quail, Colinus virginianus, (8) and mallard, Anas platyrhynchos, (6), the two test species mandated by regulatory approval schemes in North America; and the most commonly tested fish were rainbow trout, Oncorhynchus mykiss, (6) and Nile tilapia, Oreochromis niloticus, (6).

Most of these studies investigated the effects of the two neonicotinoids, imidacloprid (72) and clothianidin (19), as well as fipronil (47); between them, these three insecticides accounted for $91 \%$ of all studies. Given the paucity of information collated for the other neonicotinoids, this review concentrates on these three products alone.

\section{The direct effects of neonicotinoids and fipronil on vertebrate wildlife}

\section{Toxicity to vertebrates}

Standard toxicity testing for pesticides on terrestrial vertebrates is through an acute $(<96 \mathrm{~h})$ study. Test organisms are given the product by gavage (i.e. through a feeding tube) or through the diet in varying concentrations, and the estimated dose of pesticide associated with death of half of the test subjects is recorded and expressed as a proportion of bodyweight (i.e. the $50 \%$ lethal dose, $\mathrm{LD}_{50}$, expressed as milligrams of pesticide per kilogram of bodyweight). Toxicity for aquatic organisms is typically measured as the $\mathrm{LC}_{50}$ or the concentration in water (e.g. $\mathrm{mg} / \mathrm{L}$ ) which is toxic to the test organisms. Numerous $\mathrm{LD}_{50}$ and $\mathrm{LC}_{50}$ tests have been undertaken for vertebrates, and those that were located as part of this review are shown for imidacloprid, clothianidin and fipronil in Table 1. As can be seen, the relative toxicity of these products varies, both among products and among species.
The US Environmental Protection Agency has developed an ecotoxicity classification based on $\mathrm{LD}_{50}$ and $\mathrm{LC}_{50}$ assessments (US EPA 2012). They classify the acute toxicity of a given product on a particular species as either practically nontoxic, slightly toxic, moderately toxic, highly toxic, or very highly toxic based on lethality dose ranges. Sub-lethal or reproductive effects are not included in this classification. By US EPA's definitions, and within the highly restricted range of species assessed, imidacloprid shows moderate to high toxicity to birds, particularly for smaller-bodied species such as house sparrows, Passer domesticus, and canaries, Serinus canaria, and approaches very high toxicity to grey partridge, Perdix perdix. It is moderately toxic to rats and mice, but practically non-toxic to fish (with the exception of rainbow trout, especially their fry) and amphibians. Clothianidin's toxicity ranges from moderate to practically non-toxic for both birds and mammals, whereas for the fish studied, it varies from slightly toxic to practically non-toxic. By contrast, for all fish species studied, fipronil is either highly or very highly toxic (e.g. bluegill sunfish, Lepomis macrochirus). Fipronil is in addition highly toxic to the three game birds studied (red-legged partridge, Alectoris rufa, ringnecked pheasant, Phasianus colchicus, and northern bobwhite quail), and moderately toxic to mice and rats.

One of the serious failings of current risk assessments is the underestimation of interspecies variation in insecticide susceptibility that is apparent from Table 1 . Too few species are typically tested to derive the true variation in response from the vast array of exposed species in the wild. Mineau and Palmer (2013) discuss this at length for neonicotinoids and propose improved thresholds derived from species sensitivity distributions and estimated 'hazard doses' $\left(\mathrm{HD}_{5}\right.$ - the $\mathrm{LD}_{50}$ value for a species at the $5 \%$ tail of the sensitivity distribution).

Impacts on growth, development and reproduction of vertebrates

While not necessarily causing mortality among adults, intoxication by imidacloprid, clothianidin and fipronil can reduce the growth, development and reproduction of individual vertebrates (Table 2). Reproductive effects are manifest in a variety of ways among mammals, but especially as reduced sperm production, adverse effects on the fertilization process, reduced rates of pregnancy, higher rates of embryo death, stillbirth and premature birth, and reduced weights of offspring. Among birds, testicular anomalies and reduced fertilization success, reduced eggshell thickness and embryo size, reduced hatching success and chick survival, and chick developmental abnormalities have all been reported. Weight loss, or impaired weight gain, sometimes associated with reduction or cessation of feeding, occurred within all taxa studied. 
Table 1 Single (acute) dose $\mathrm{LD}_{50}$ (for mammals birds and reptiles, $\mathrm{mg} / \mathrm{kg}$ ) and $\mathrm{LC}_{50}$ (for fish and amphibia, $\mathrm{mg} / \mathrm{L}$ ) for imidacloprid, clothianidin and fipronil

\begin{tabular}{|c|c|c|c|c|}
\hline Taxon & Species & Imidacloprid & Clothianidin & Fipronil \\
\hline \multirow[t]{2}{*}{ Mammal } & Rat, Rattus norvegicus & $425-475(\mathrm{MT})^{\mathrm{a}}$ & $5,000(\mathrm{PNT})^{\mathrm{i}}$ & $97(\mathrm{MT})^{1}$ \\
\hline & Mouse, Mus musculus & $131-300(\mathrm{MT})^{\mathrm{a}}$ & $>389(\mathrm{MT})^{\mathrm{i}}$ & $95(\mathrm{MT})^{\mathrm{m}}$ \\
\hline \multirow[t]{11}{*}{ Bird } & Mallard, Anas platyrhynchos & $283(\mathrm{MT})^{\mathrm{b}}$ & $>752(\mathrm{ST})^{\mathrm{j}}$ & $2,150(\mathrm{PNT})^{1}$ \\
\hline & Ring-necked pheasant, Phasianus colchicus & & & $31(\mathrm{HT})^{1}$ \\
\hline & Grey partridge, Perdix perdix & $13.9(\mathrm{HT})^{\mathrm{c}}$ & & \\
\hline & Red-legged partridge, Alectoris rufa & & & $34(\mathrm{HT})^{1}$ \\
\hline & Northern bobwhite quail, Colinus virginianus & $152(\mathrm{MT})^{\mathrm{a}}$ & $>2,000(\mathrm{PNT})^{\mathrm{k}}$ & $11.3(\mathrm{HT})^{1}$ \\
\hline & Japanese quail, Coturnix japonica & $31(\mathrm{HT})^{\mathrm{a}}$ & $423(\mathrm{MT})^{\mathrm{k}}$ & \\
\hline & Feral pigeon, Columba livia & $25-50(\mathrm{HT})^{\mathrm{a}}$ & & $>2,000(\mathrm{PNT})^{1}$ \\
\hline & House sparrow, Passer domesticus & $41(\mathrm{HT})^{\mathrm{a}}$ & & \\
\hline & Field sparrow, Spizella pusilla & & & $1,120(\mathrm{ST})^{1}$ \\
\hline & Canary, Serinus canaria & $25-50(\mathrm{HT})^{\mathrm{a}}$ & & \\
\hline & Zebra finch, Taeniopygia guttata & & & $310(\mathrm{MT})^{\mathrm{n}}$ \\
\hline \multirow[t]{7}{*}{ Fish } & Bluegill sunfish, Lepomis macrochirus & $105(\mathrm{PNT})^{\mathrm{a}}$ & $>117(\mathrm{PNT})^{\mathrm{i}}$ & $0.083(\mathrm{VHT})^{1}$ \\
\hline & Japanese carp, Cyprinus carpio & & & $0.34(\mathrm{HT})^{1}$ \\
\hline & Nile tilapia, Oreochromis niloticus & & & $0.042-0.147\left(\right.$ VHT-HT) ${ }^{1}$ \\
\hline & Rainbow trout, Oncorhynchus mykiss & $>83-211\left(\right.$ ST-PNT) ${ }^{\mathrm{a}}$ & $>105(\mathrm{PNT})^{\mathrm{i}}$ & $0.246(\mathrm{HT})^{1}$ \\
\hline & Rainbow trout (fry) & $1.2(\mathrm{MT})^{\mathrm{d}}$ & & \\
\hline & Sheepshead minnow, Cyprinodon variegatus & $161(\mathrm{PNT})^{\mathrm{a}}$ & $>93.6(\mathrm{ST})^{\mathrm{i}}$ & $0.13(\mathrm{HT})^{1}$ \\
\hline & Zebrafish, Danio rerio & $241(\mathrm{PNT})^{\mathrm{e}}$ & & \\
\hline \multirow[t]{4}{*}{ Amphibia } & Black-spotted pond frog, Rana nigromaculata & $129-219(\mathrm{PNT})^{\mathrm{a}, \mathrm{f}}$ & & \\
\hline & Indian rice frog, Rana limnocharis & $82-366(\text { ST-PNT) })^{a, f, g}$ & & \\
\hline & Western chorus frog, Pseudacris triseriata & $194(\mathrm{PNT})^{\mathrm{h}}$ & & \\
\hline & American toad, Bufo americanus & $234(\mathrm{PNT})^{\mathrm{h}}$ & & \\
\hline Reptile & Fringe-toed lizard, Acanthodactylus dumerili & & & $30(\mathrm{HT})^{\mathrm{o}}$ \\
\hline
\end{tabular}

Toxicity classification follows US EPA (2012): $P N T$ practically non-toxic, $S T$ slightly toxic, $M T$ moderately toxic, $H T$ highly toxic, $V H T$ very highly toxic. For birds, mammals and reptiles: PNT $>2,000$, ST 501-2,000, MT 51-500, HT 10-50, VHT <10. For aquatic organisms, fish and amphibia: PNT $>100$, ST $>10-100, \mathrm{MT}>1-10$, HT 0.1-1, VHT $<0.1$. Note that $\mathrm{kg}$ in the $\mathrm{LD}_{50}$ units refers to body weight of the dosed animal. Source references denoted by superscripts are as follows: ${ }^{\mathrm{a}}$ SERA $2005,{ }^{\mathrm{b}}$ Fossen $2006,{ }^{\mathrm{c}}$ Grolleau 1991 in Anon 2012, ${ }^{\mathrm{d}}$ Cox 2001, ${ }^{\mathrm{e}}$ Tisler et al. 2009, ${ }^{\mathrm{f}}$ Feng et al. 2004, ${ }^{\mathrm{g}}$ Nian $2009,{ }^{\mathrm{h}}$ Howard et al. 2003, ${ }^{\mathrm{i}}$ DeCant and Barrett 2010, ${ }_{\mathrm{j}}$ European Commission 2005, ${ }^{\mathrm{k}}$ Mineau and Palmer 2013, ${ }^{1}$ Tingle et al. 2003, ${ }^{\mathrm{m}}$ Connelly 2011, ${ }^{\mathrm{n}}$ Kitulagodage et al. 2008 (NB : a formulation of fipronil containing the dispersant solvent diacetone alcohol was sevenfold more toxic than technical grade fipronil itself), ${ }^{\circ}$ Peveling and Demba 2003 (NB: $42 \%$, rather than $50 \%$, mortality)

Most of the studies found were required for pesticide registration purposes. In birds, a reproductive test is frequently conducted on standard test species such as the northern bobwhite quail or the mallard. This is a truncated test, which consists of feeding a constant concentration of the pesticide to the study animals and then collecting the eggs and incubating them artificially. There is therefore no inclusion of endpoints to assess the ability of the dosed birds to incubate, hatch or raise their young. The test is a hybrid between single life stage chronic toxicity and a test of true reproductive effects, and has been the subject of analysis and criticism (Mineau et al. 1994, 1996; Mineau 2005). Because of the longer duration of the test, and the occasional pair that fails to bond, spurious variance is introduced, thus decreasing the power to detect reproductive deficits in limited sample sizes. On the other hand, because the birds are offered contaminated diet only, with no other food choice, the test may overestimate realistic exposure in the wild. However, it remains the only test available with which to model non-acute risk in avian wildlife.

Other sub-lethal impacts on vertebrates

A range of other effects of these insecticides have been documented for vertebrates (Table 2), outside of those reported on survival, growth and development, and reproduction. Among mammals - principally rats and mice-these include genotoxic and cytotoxic effects, neuro-behavioural disorders of offspring (including those dosed in utero), lesions of the thyroid, retinal atrophy, reduced movement, and increased measures of anxiety and fear. House sparrows can become uncoordinated and unable to fly, and studies of Japanese quail and red-legged partridges have reported DNA breakages and a reduced immune response, respectively. Similarly, studies of 


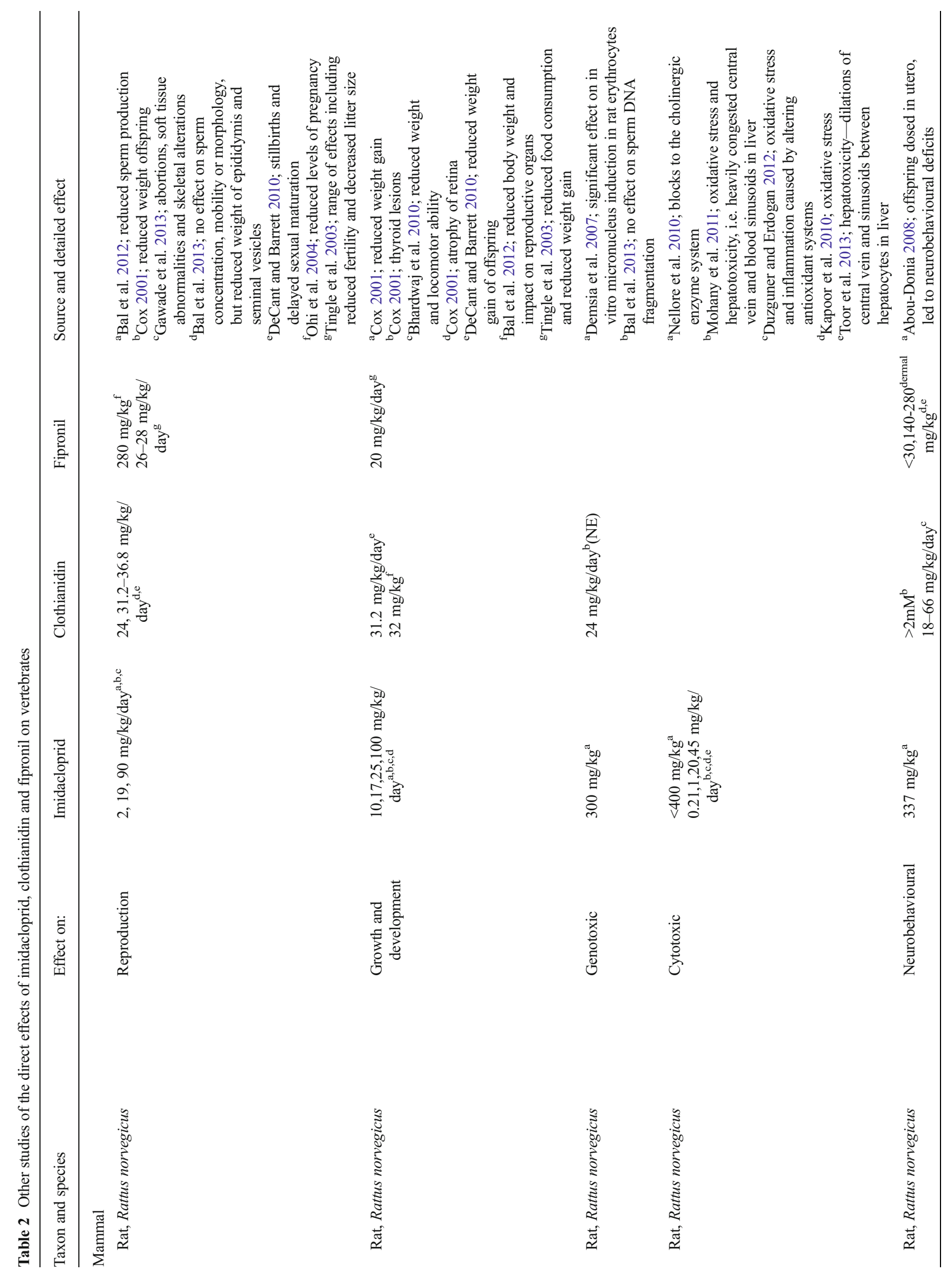




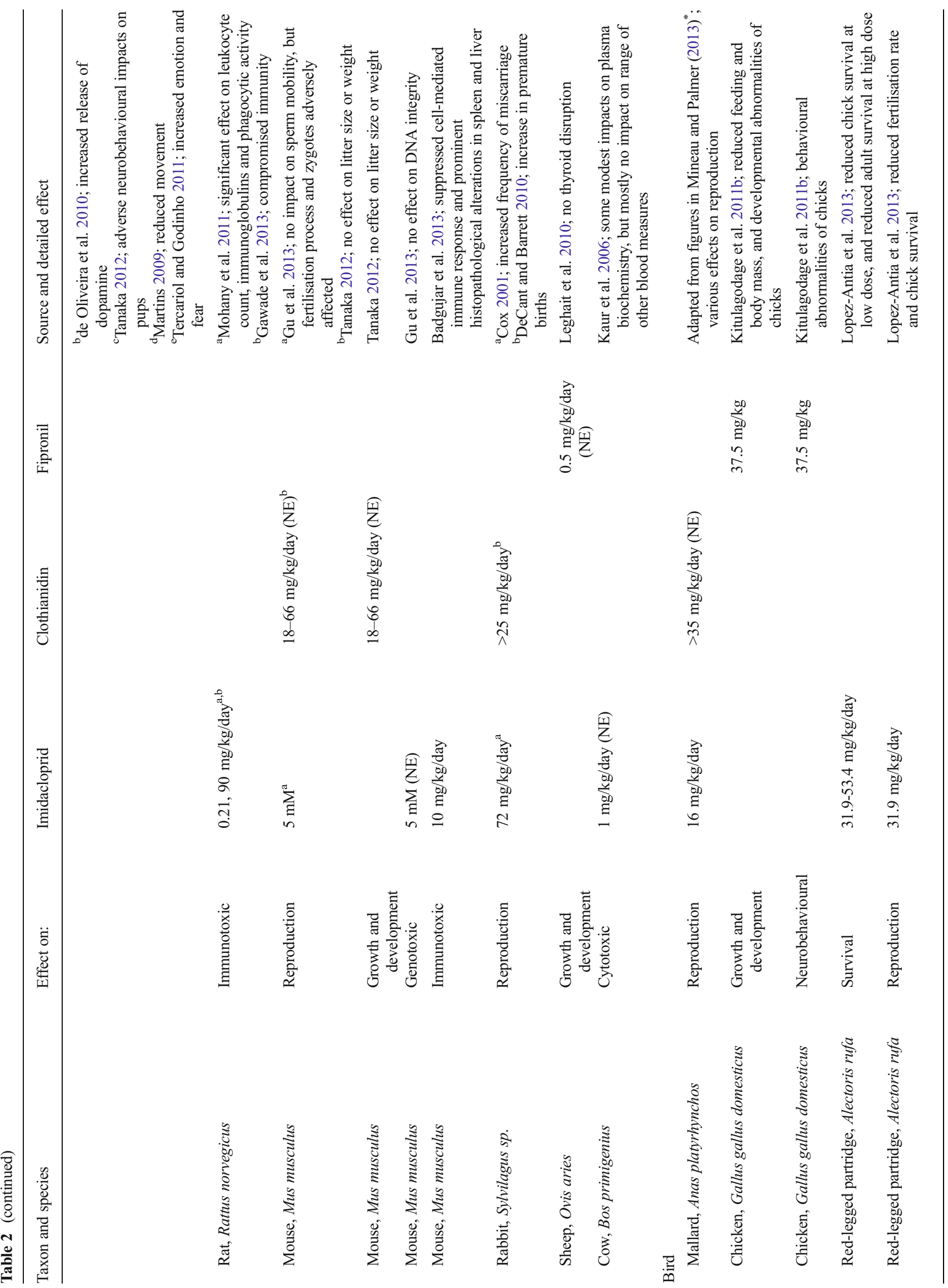



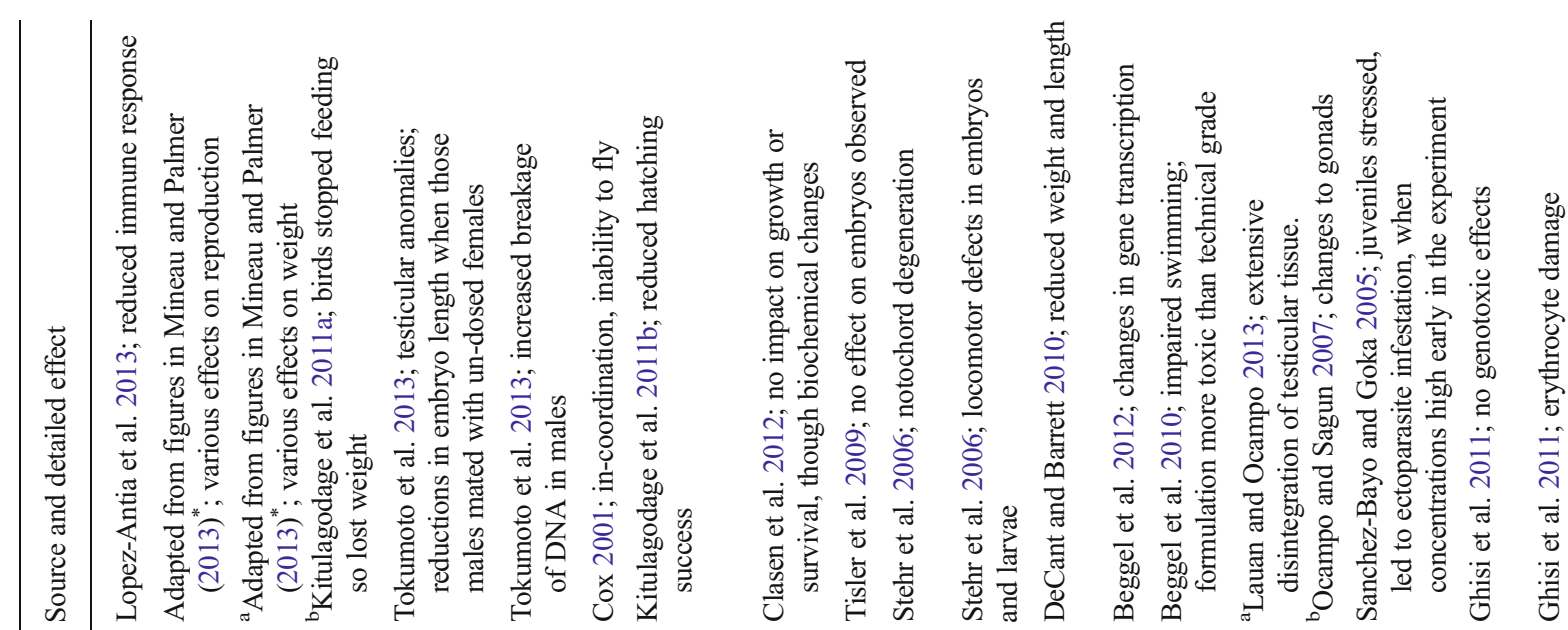

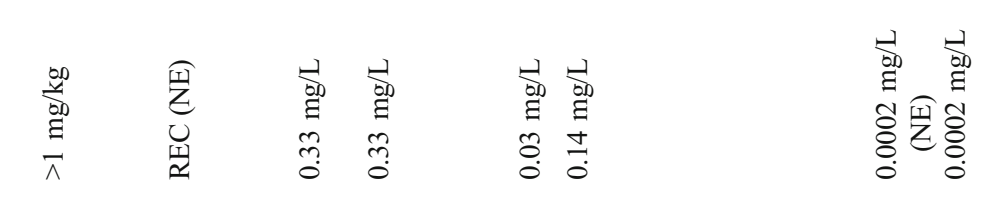

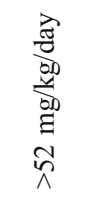

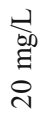

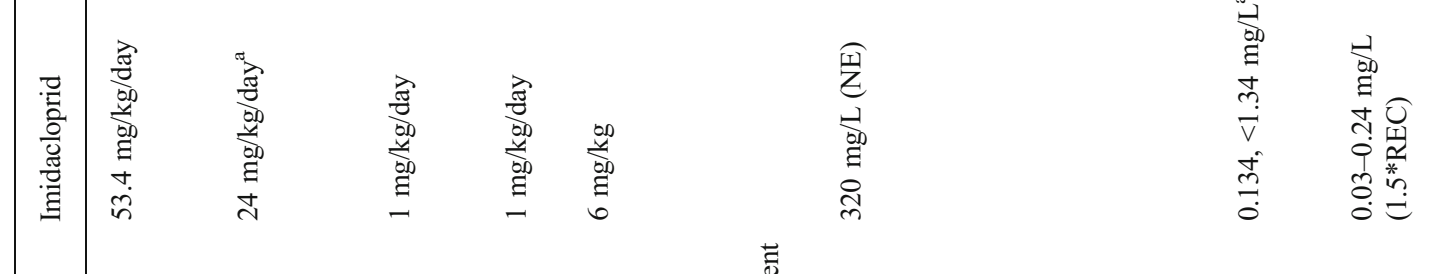

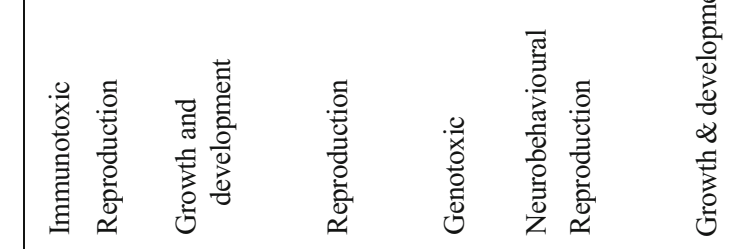
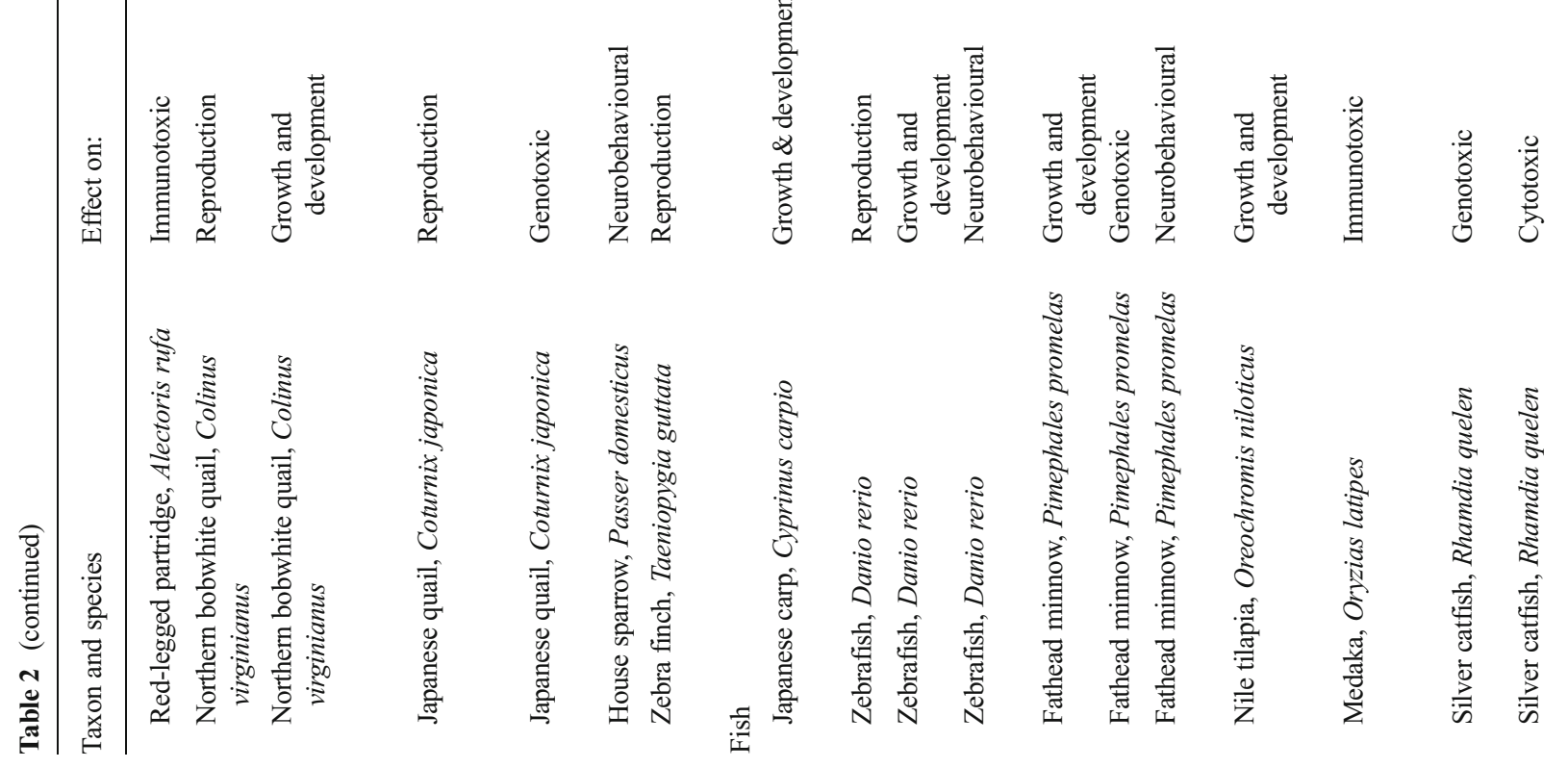
fish have reported changes in gene transcription, erythrocyte damage, disintegration of gonadal tissue, impaired swimming, notochord degeneration and locomotor defects in embryos and larvae. In one case, medaka fish, Oryzias latipes, in experimental rice fields became physiologically stressed (characterized by increased anaerobic metabolism leading to hyperglycemia) following exposure to imidacloprid at 1.5 times the commercially recommended rate of application, and subsequently became susceptible to infestation by the protozoan ectoparasite, Cychlochaeta (Trichodina) domerguei (Sánchez-Bayo and Goka 2005). While the majority of studies documented deleterious impacts from neonicotinoid or fipronil exposure, effective doses have not typically been matched to realistic field exposure conditions.

Many of these, perhaps, more subtle sub-lethal effects (Table 2) occur at much lower concentrations than lethal effects (Table 1). Thus, while single oral doses of 425-475 and $5,000 \mathrm{mg} / \mathrm{kg}$ of imidacloprid and clothianidin, respectively, will kill rats, lower daily doses of $0.21-100$ and 18 $66 \mathrm{mg} / \mathrm{kg} /$ day have consistently caused a range of sub-lethal effects. For example, a daily dose of 10-19 or $31 \mathrm{mg} / \mathrm{kg} / \mathrm{day}$ of imidacloprid and clothianidin, respectively, will cause reduced growth of young rats and, in the case of clothianidin, a greater frequency of stillbirths. Even doses as low as 0.21 and $2.0 \mathrm{mg} / \mathrm{kg} / \mathrm{day}$ of imidacloprid have been shown to have immunotoxic effects and reduce sperm production, respectively. Similarly, while a single oral dose of $41 \mathrm{mg} / \mathrm{kg}$ of imidacloprid will cause mortality in house sparrows, a substantially lower dose $(6 \mathrm{mg} / \mathrm{kg})$ can induce uncoordinated behaviour and an inability to fly. While imidacloprid is highly toxic to Japanese quail, with an $\mathrm{LD}_{50}$ of $31 \mathrm{mg} / \mathrm{kg}$, chronic daily doses of only $1 \mathrm{mg} / \mathrm{kg}$ /day can lead to testicular anomalies, DNA damage in males, and reductions in embryo size when those males are mated with control females. The blackspotted pond frog has an $\mathrm{LC}_{50}$ of $129-219 \mathrm{mg} / \mathrm{L}$ of imidacloprid, but DNA damage occurs at a much lower concentration, $0.05 \mathrm{mg} / \mathrm{L}$. Given the high toxicity of fipronil to fish, it is perhaps not surprising that the lowest recorded concentration of that insecticide to affect a vertebrate was of $0.0002 \mathrm{mg} / \mathrm{L}(0.2 \mu \mathrm{g} / \mathrm{L})$; the effect being erythrocyte damage in silver catfish, Rhamdia quelen. While it is difficult to extrapolate such sub-organism effects to fitness-related measures in individuals and population-level responses, they offer insight into potential mechanisms underpinning direct toxicity.

Different families of pesticides rarely elicit sub-lethal effects at doses below 1/10 of the lethal dose (Callahan and Mineau 2008). But, in the case of imidacloprid, signs of severe debilitation (e.g. ataxia) were observed a full order of magnitude below lethal doses. Review of available laboratory data here suggests that some effects can be detected at even lower doses $(1 / 1,000)$. This apparent feature of these insecticides is of toxicological concern with respect to vertebrates, increasing 
the probability that wild species can be affected under fieldrealistic exposure conditions.

Are vertebrates at risk in their natural environment?

\section{Risks to aquatic vertebrates}

Various measured or estimated environmental concentrations of imidacloprid, clothianidin and fipronil in the aquatic environment are available. For imidiacloprid, these include 0$0.22 \mu \mathrm{g} / \mathrm{L}$ (Lamers et al. 2011); mean and maximum values of 0.016 and $0.27 \mu \mathrm{g} / \mathrm{L}$, respectively (Main et al. 2014); 0.13$0.14 \mu \mathrm{g} / \mathrm{L}$ (Stoughton et al. 2008); 0-3.3 $\mu \mathrm{g} / \mathrm{L}$ (Starner and Goh 2012); 1-14 $\mu \mathrm{g} / \mathrm{L}$ (Jemec et al. 2007); $<15 \mu \mathrm{g} / \mathrm{L}$ (Kreuger et al. 2010); 17-36 $\mu \mathrm{g} / \mathrm{L}$ (Fossen 2006); and up to $49 \mu \mathrm{g} / \mathrm{L}$ (Hayasaka et al. 2012). Higher concentrations of imidacloprid have been more rarely recorded in the aquatic environment. In one study in the Netherlands, while $98 \%$ of 1,465 measurements ranged from 0 to $8.1 \mu \mathrm{g} / \mathrm{L}$, the remaining $2 \%$ were up to $320 \mu \mathrm{g} / \mathrm{L}$ (Van Dijk et al. 2013). Similarly, in a study in experimental rice fields, the concentration of imidacloprid immediately after application was $240 \mu \mathrm{g} / \mathrm{L}$, but fell to $5 \mu \mathrm{g} / \mathrm{L}$ within a week (Sánchez-Bayo and Goka 2005). For clothianidin, DeCant and Barrett (2010) estimated concentrations of $0.5-3.0 \mu \mathrm{g} / \mathrm{L}$ for standing water surrounding two crops, while Main et al. (2014) measured mean and maximum concentrations of 0.14 and $3.1 \mu \mathrm{g} / \mathrm{L}$, respectively, in water bodies beside canola fields. Measurements for fipronil in the aquatic environment have been reported at $0.17 \mu \mathrm{g} / \mathrm{L}$ (Stark and Vargas 2005); a median of 0.23 and range of 0.004-6.4 $\mu \mathrm{g} / \mathrm{L}$ (Mize et al. 2008); $1 \mu \mathrm{g} / \mathrm{L}$ (Hayasaka et al. 2012); and 0.15-5 $\mu \mathrm{g} / \mathrm{L}$ (Wirth et al. 2004).

Imidacloprid $\mathrm{LC}_{50}$ measurements for fish and amphibia (Table 1) range from 1,200 to $366,000 \mu \mathrm{g} / \mathrm{L}$, and for clothianidin, from 94,000 to $117,000 \mu \mathrm{g} / \mathrm{L}$ (fish only). Thus, except in the most extreme cases, environmental concentrations are from approximately 2 to 7 orders of magnitude lower than $\mathrm{LC}_{50}$ measurements for fish and amphibians, so it is unlikely that the mortality rates of these taxa will be directly affected by these two insecticides under normal exposure. However, the possibility of sub-lethal effects, e.g. physiological stress and damage to DNA, cannot be ruled out (Table 2). For fipronil, there is a greater apparent risk to fish survival, as some of the highest environmental concentrations are within an order of magnitude of their $\mathrm{LC}_{50}$ values (Table 1), especially for bluegill sunfish and Nile tilapia. Sub-organism effects may also be apparent, for example, erythrocyte damage and alterations to gene transcription (Table 2).

\section{Risks to terrestrial vertebrates}

Determining the exposure risks to terrestrial vertebrates is more complex than to aquatic species given that there are several routes of exposure, e.g. from ingestion of treated seed; from residues in or on the crop and soil; from drinking water, nearby vegetation or invertebrates; from dermal exposure due to direct overspray or contact with treated surfaces; from inhalation; and even from preening. Concentrations to which terrestrial taxa can be exposed vary markedly within and between these different pathways, based on habitat requirements and movement between contaminated and uncontaminated patches.

Treated seeds contain some of the highest concentrations of neonicotinoids, with a typical individual canola (oilseed rape), beet or corn seed calculated to contain $0.17,0.9$ or $1 \mathrm{mg}$ of active ingredient, respectively (Goulson 2013). Application rates vary widely by crop but, for example, canola seeds treated with clothianidin have recommended application rates of $4.0 \mathrm{~g}$ a.i. $/ \mathrm{kg}$ of canola seed, while corn is almost double, at $7.5 \mathrm{~g}$ a.i./kg seed. Given these high concentrations, and that many granivorous species eat crop seeds, the most likely route of exposure to terrestrial animals is probably through the consumption of treated seeds.

Residues in crops and surrounding soil may be lower but still pose a risk to wildlife consumers that feed on the treated plants or ingest soil. For example, Bonmatin et al. (2005) found residues of $2.1-6.6 \mu \mathrm{g} / \mathrm{kg}$ of imidacloprid in seedtreated maize plants. Substantially higher concentrations of $1.0-12.4 \mathrm{mg} / \mathrm{kg}$ of imidacloprid have been detected in seedtreated sugar beet leaves (Rouchaud et al. 1994). Grounddwelling species may also be exposed via the soil. Anon (cited in Goulson 2013) found concentrations of 18-60 $\mu \mathrm{g} /$ $\mathrm{kg}$ of imidacloprid in soil following several years of repeated applications as a seed treatment on winter wheat. Donnarumma et al. (2011) measured concentrations of $652 \mu \mathrm{g} / \mathrm{kg}$ of imidacloprid in soil 30 days after sowing of dressed maize seeds, falling to $11 \mu \mathrm{g} / \mathrm{kg}$ at harvest. Following soil drenching (i.e. applying a diluted insecticide directly to the base of a plant), Cowles et al. (2006) found concentrations of $120-220 \mu \mathrm{g} / \mathrm{kg}$ of imidacloprid in hemlock, Tsuga Canadensis, tissue. Cutler and Scott-Dupree (2007) found residues of $0.5-2.6 \mu \mathrm{g} / \mathrm{kg}$ of clothianidin in seed-treated canola plants, while Krupke et al. (2012) found residues of 1$9 \mu \mathrm{g} / \mathrm{kg}$ of clothianidin on natural vegetation surrounding seed-treated maize fields. Krupke et al. (2012) also detected concentrations of $6.3 \mu \mathrm{g} / \mathrm{kg}$ of clothianidin in soil in fields sown with seed-treated maize.

The US EPA modelled the estimated daily intake of clothianidin, assuming that mammals and birds only eat a diet of treated seeds (DeCant and Barrett 2010). This risk modelling approach showed that clothianidin, at least when used to treat oilseed rape and cotton seeds, could reduce the survival of small birds and mammals (DeCant and Barrett 2010).

Similar approaches have been developed for other routes of exposure beyond ingestion of seed treatments (e.g. SERA 2005; US EPA 2012). For example, risk modelling for 
imidacloprid suggests hazards to birds and mammals consuming vegetation, grass and even insects. In particular, it predicts that foliar spraying may lead to substantial mortality of sensitive bird species (SERA 2005). In its 2008 re-assessment of imidacloprid, the US EPA (2008) reported an incident where grubs surfacing after a lawn treatment appear to have poisoned young robins, Turdus migratorius.

A more detailed assessment of the risk of intoxication of birds following the consumption of neonicotinoid-treated seed is given by Mineau and Palmer (2013). Their analysis suggests that the risks of acute intoxication with imidacloprid applied on maize, oilseeds or cereals are comparably high, such that birds need only to ingest a few treated seeds. The risk of acute intoxication with clothianidin in maize is highest, whereas for oilseeds or cereals, birds would need to ingest more, largely because application rates are lower. In principle, there are ways in which this risk could be mitigated, for example, by burying seeds below the soil surface, but this is rarely $100 \%$ effective due to spillage (de Leeuw et al. 1995; Pascual et al. 1999). Whether or not birds avoid eating treated seeds (Avery et al. 1998), or the extent to which they may remove a substantial proportion of the toxicant by discarding outer seed husks (Avery et al. 1997) have been debated. However, incidents of bird poisoning with imidaclopridtreated seed have been documented (Berny et al. 1999), suggesting that the calculated risk may be real.

The potential risk to birds from eating neonicotinoidtreated seeds can be illustrated by the following example in which we calculate the relative risk for two granivorous species, a grey partridge, Perdix perdix (mass $\sim 390 \mathrm{~g}$ ) and a house sparrow (mass $\sim 34 \mathrm{~g}$ ) (http://blx1.bto.org/birdfacts/results/ bob3670.htm), feeding on a field recently sown with imidacloprid-treated beet seed, each containing $0.9 \mathrm{mg}$ of imidacloprid (Anon 2012). Imidacloprid is highly toxic to both species, with a $\mathrm{LD}_{50}$ of $13.9 \mathrm{mg} / \mathrm{kg}$ of body weight for grey partridge and $41 \mathrm{mg} / \mathrm{kg}$ for house sparrow (Table 1). Consequently, ingestion of just 6 and 1.5 seeds would have a $50 \%$ chance of killing an individual foraging partridge and sparrow, respectively. Less than a quarter of a seed could have a sub-lethal effect on a house sparrow, as $6 \mathrm{mg} / \mathrm{kg}$ is sufficient to reduce flying ability (Table 2; Cox 2001). While de Leeuw et al. (1995) suggest that only $0.17 \%$ of beet seeds remain on the soil surface after sowing, at a maximum drilling rate of 130,000 seeds per hectare (Anon 2012), 6 and 1.5 seeds would be found on the surface in areas of approximately 270 and $70 \mathrm{~m}^{2}$, respectively, well within the daily foraging ranges of each species. Areas of accidentally spilled seed could contain much higher densities. While individual partridges and sparrows may not ingest treated seeds (i.e. as the brightly coloured seed coatings may deter birds if they represent a novel food source), these calculations suggest that there is a potential risk of imidacloprid-treated seeds to affect sensitive bird species, consistent with conclusions drawn by DeCant and Barrett
(2010), Mineau and Palmer (2013) and Goulson (2013). Anecdotal observations of blackbirds and sparrows foraging in fields recently seeded with neonicotinoid-treated crops suggest that the calculated risks are further plausible (C. Morrissey personal observation).

\section{The indirect effects of pesticides on vertebrate wildlife}

While rarely considered in ecological risk assessments, concerns about the impacts of pesticide use on vertebrates have more recently turned to the widespread potential for indirect effects (Sotherton and Holland 2002; Boatman et al. 2004). Observations of farmland and grassland bird declines and range contractions correlate well with agricultural intensification, including increased pesticide use (Chamberlain et al. 2000; Morris et al. 2005; Ghilain and Bélisle 2008; Robillard et al. 2013; Mineau and Whiteside 2013). Tennekes (2010) and Mason et al. (2012) have recently suggested, albeit with little supporting evidence, that neonicotinoid insecticides may be contributing to declines of insectivorous birds in Europe, and of fish, amphibians, bats and birds around the world, respectively. Tennekes (2010) hypothesized that neonicotinoids were acting indirectly on bird populations, by reducing the abundance of their insect prey. Mason et al. (2012) suggested that neonicotinoids have suppressed the immune system of vertebrates (and invertebrates) making them more prone to infectious disease and other stressors.

Indirect effects of pesticides on vertebrates are most commonly exerted in one of three ways: (1) through reductions of plant seed food for granivores following herbicide applications (e.g. Gibbons et al. 2006); (2) through the loss of insect host plants following herbicide applications and the secondary impacts for dependent insects and insectivores, (e.g. Potts 1986); or (3) through reductions in arthropod prey for insectivores following applications of insecticides - or fungicides with insecticidal properties (e.g. Martin et al. 2000; Morris et al. 2005; Poulin et al. 2010).

Indirect effects are inherently difficult to measure and frequently suffer from limitations of correlative inferences. Boatman et al. (2004) highlighted three criteria for conclusively inferring a causal link between pesticides and their indirect actions on vertebrate wildlife. Conclusive studies should document negative effects on (1) food quality and quantity, (2) reproduction, condition or survivorship of the vertebrate consumer and (3) concomitant vertebrate population declines. The only documented case where indirect effects were definitively shown using the full range of these criteria in a fully replicated field experiment was for the grey partridge in Britain (Rands 1985) following several decades of intensive study. Population modelling showed that declines in grey partridge populations could be wholly explained by 
herbicide-induced reductions in prey availability in tandem with reduced growth and survival of grey partridge chicks (reviewed by Potts 1986). Other studies, however, have revealed consistent effects on one or more of these three criteria, suggesting that the indirect effects of pesticides may be more prevalent than documented in the literature.

Studies reporting effects on consumers through food reductions

Pesticide applications, in temperate regions, directly overlap with the seasonal production of invertebrates and the breeding seasons of a range of numerous vertebrate species. Food supply (i.e. abundance and availability) is widely accepted as affecting habitat selection, reproductive success and survival in vertebrates, with extensive supporting evidence for birds in particular (Simons and Martin 1990; Johansson and Blomqvist 1996; Brickle et al. 2000; Moller 2001; Hole et al. 2002; Nagy and Holmes 2004, 2005; Boatman et al. 2004; Morris et al. 2005; Britschgi et al. 2006; Hart et al. 2006; Zanette et al. 2006; Golawski and Meissner 2008; Selås et al. 2008; Dunn et al. 2010; Poulin et al. 2010). Across Europe and North America, dramatic and widespread declines have been observed in populations of birds associated with farmland and wetland habitats (Beauchamp et al. 1996; Donald et al. 2001; Benton et al. 2002; Boatman et al. 2004), with arthropod abundance showing similar trends (Benton et al. 2002). In Canada and the USA, however, species loss has been more strongly correlated with pesticide use than agricultural area or intensification measures alone (Gibbs et al. 2009; Mineau and Whiteside 2013).

Reductions in invertebrate food abundance caused by insecticide use has been linked to reductions in reproductive success of at least four farmland passerines in the UK: corn bunting, Miliaria calandra, yellowhammer, Emberiza citrinella, whinchat, Saxicola rubetra, and reed bunting, Emberiza schoeniclus (Brickle et al. 2000; Brickle and Peach 2004; Morris et al. 2005; Hart et al. 2006; Dunn et al. 2010; but see Bradbury et al. 2000, 2003). Although declines in bird populations in the UK have been coincident with invertebrate losses, changes in invertebrate abundance alone do not fully explain population trends for these species. In fact, the nesting success of these species increased during time periods when populations were declining (Siriwardena et al. 2000). Population declines of seed eaters have instead been linked to reduced over-winter survival, likely as a consequence of reduced seed availability (Siriwardena et al. 2000; Butler et al. 2010).

Indirect effects of neonicotinoids and fipronil

We found only six studies that have investigated the indirect effects of neonicotinoids and fipronil on vertebrate wildlife
(Table 3). All were field rather than laboratory-based studies. Of these studies, one found a beneficial, indirect effect. Female Cape ground squirrels, Xerus inauris, benefited from ectoparasite removal with fipronil and had fourfold higher breeding success (Hillegass et al. 2010). A number of studies have shown that reducing parasite burdens can enhance vertebrate breeding success (e.g. Hudson et al. 1992). However, interpretation of the effect of fipronil was not straightforward, as endoparasites were simultaneously removed with ivermectin, and researchers could not distinguish the effects of the two products.

In two further field studies, both in experimental rice fields, imidacloprid and/or fipronil was applied at the recommended commercial rates. While one study found no effect of fipronil on growth or survival of Japanese carp, Cyprinus carpio (Clasen et al. 2012), the other found that both imidacloprid and fipronil applications reduced the growth of both adult and fry medaka fish, Oryzias latipes (Hayasaka et al. 2012). Hayasaka et al. (2012) suggest that this is most likely an indirect effect, through a reduction in the abundance of medaka prey. The concentrations were probably too low (approximately 0.001 to $0.05 \mathrm{mg} / \mathrm{L}$ ) to exert a direct toxic effect on medaka but assumed sufficiently high to reduce the abundance of their invertebrate prey.

Population-level studies investigating indirect impacts of neonicotinoids and fipronil on vertebrate species are rare. Only three such studies were found during this review, and all were of local - rather than national or regional-populations (Table 3). All were field studies that applied either imidacloprid or fipronil at recommended commercial rates using sprays or soil drenching, rather than seed treatments.

Falcone and DeWald (2010) investigated the impact of a single soil drenching application with imidacloprid on eastern hemlock, Tsuga Canadensis, as part of a campaign to reduce numbers of an exotic insect pest. While the soil drenching had (surprisingly) no impact on the woolly adelgid (Adelges tsugae) pest, populations of non-target hemiptera and lepidoptera were reduced. Despite lepidopteran larvae being important in the diet of three neotropical migrant insectivorous bird species, bird numbers were not affected in the following year. Norelius and Lockwood (1999) undertook a similar study, this time spraying with fipronil to control a grasshopper outbreak. While grasshopper numbers were markedly reduced, populations of insectivorous prairie birds that commonly consume the grasshoppers were slightly, but not significantly, reduced a month after spraying. The lack of clear population-level effects in both these studies may have been related to birds seeking food outside treated areas in compensation, although this seems unlikely, at least for the Norelius and Lockwood (1999) study, as the home ranges of the birds studied (few hectares) were small compared to the total treated area (few hundred hectares). Alternatively, population-level effects could have been masked in such 
Table 3 Indirect effects of imidacloprid and fipronil on vertebrates

\begin{tabular}{|c|c|c|c|c|}
\hline Taxon and Species & Effect on: & Imidacloprid & Fipronil & Source and detailed effect \\
\hline \multicolumn{5}{|l|}{ Mammal } \\
\hline $\begin{array}{l}\text { Lesser hedgehog tenrec, } \\
\text { Echinops telfairi }\end{array}$ & Population & & REC & $\begin{array}{l}\text { Peveling et al. 2003; marked reduction } \\
\text { in harvester termite prey may eventually } \\
\text { lead to tenrec decline }\end{array}$ \\
\hline $\begin{array}{l}\text { Cape ground squirrel, Xerus } \\
\text { inauris }\end{array}$ & Reproduction & & $\begin{array}{l}0.7 \mathrm{mg} / \mathrm{kg} ; \mathrm{REC} \\
\quad(\mathrm{POS})\end{array}$ & $\begin{array}{l}\text { Hillegass et al. 2010; removal of ectoparasites } \\
\text { (with fipronil) and endoparasites boosted } \\
\text { breeding success; unable to determine impact } \\
\text { of fipronil alone }\end{array}$ \\
\hline \multicolumn{5}{|l|}{ Bird } \\
\hline $\begin{array}{l}3 \text { neotropical migrant } \\
\text { insectivores }\end{array}$ & Population & REC (NE) & & $\begin{array}{l}\text { Falcone and DeWald 2010; spraying reduced } \\
\text { lepidopteran prey, but not populations of } \\
\text { black- } \\
\text { throated green warbler (Dendroica virens), } \\
\text { black-throated blue warbler (D. caerulescens) } \\
\text { and blue-headed vireo (Vireo solitarius) }\end{array}$ \\
\hline $\begin{array}{l}38 \text { species, of which } 33 \text { were } \\
\text { insectivores }\end{array}$ & Population & & REC (NE) & $\begin{array}{l}\text { Norelius and Lockwood 1999; marked reduction } \\
\text { in grasshoppers, but not in bird densities; } 34 \\
\text { bird } \\
\text { species studied, most abundant were horned } \\
\text { lark, } \\
\text { Eremophila alpestris, western meadowlark, } \\
\text { Sturnella neglecta, and lark sparrow, } \\
\text { Chondestes } \\
\text { grammacus }\end{array}$ \\
\hline \multicolumn{5}{|l|}{ Fish } \\
\hline Medaka, Oryzias latipes & $\begin{array}{l}\text { Growth \& } \\
\text { development }\end{array}$ & $\begin{array}{l}0.001 \mathrm{mg} / \mathrm{L} \\
\quad \mathrm{REC}\end{array}$ & $\begin{array}{l}0.001-0.05 \mathrm{mg} / \mathrm{L} \\
\quad \text { REC }\end{array}$ & $\begin{array}{l}\text { Hayasaka et al. 2012; reduced growth of } \\
\text { both adults and fry }\end{array}$ \\
\hline Japanese carp, Cyprinus carpus & Growth and survival & & REC (NE) & $\begin{array}{l}\text { Clasen et al. 2012; no effect on growth and } \\
\text { survival of Japanese carp }\end{array}$ \\
\hline \multicolumn{5}{|l|}{ Reptile } \\
\hline $\begin{array}{l}\text { Madagascar iguana, } \\
\text { Chalarodon } \\
\text { madagascariensis }\end{array}$ & Population & & $\mathrm{REC}^{7}$ & $\begin{array}{l}\text { Peveling et al. 2003; marked reduction in } \\
\text { harvester termite prey led to decline in } \\
\text { iguana population }\end{array}$ \\
\hline A skink, Mabuy elegans & Population & & $\mathrm{REC}^{7}$ & $\begin{array}{l}\text { Peveling et al. 2003; marked reduction in } \\
\text { harvester termite prey led to decline in } \\
\text { skink population }\end{array}$ \\
\hline
\end{tabular}

All other studies demonstrated deleterious effects

$R E C$ insecticide applied at manufacturer's recommended rate, $N E$ no effect at the given dosage, $P O S$ positive effect at the given dosage

relatively small-scale field trials if birds had immigrated into the treated plots from surrounding un-treated areas. Neither study, however, measured breeding success or impacts on chick survival which may be more plausible than effects on adult survival.

In contrast, Peveling et al. (2003) documented how fipronil spraying to control a plague of migratory locusts in Madagascar halved populations of the harvester termite, Coarctotermes clepsydra. Consequently, populations of two lizard species, the Madagascar iguana, Chalarodon madagascariensis, and a skink, Mabuy elegans, declined, because termites form an important part of the diet of both species, while the lesser hedgehog tenrec, Echinops telfairi, may have also been affected. To date, this is the only study that has demonstrated a population-level impact of a systemic insecticide on a vertebrate population, where its effect was exerted indirectly through the food chain. While Tingle et al. (2003) report that a study of fipronil spraying to control locusts in Madagascar may have caused population declines of two bird species, Madagascar bee-eater, Merops superciliosus, and Madagascar kestrel, Falco newtoni, (but no effect on two others, Madagascar bush lark, Mirafra hova, and Madagascar cisticola, Cisticola cherina), sample sizes were too small to be conclusive, and it was not possible to distinguish between direct and indirect effects.

While it is possible to use laboratory toxicity studies to inform models on the indirect effects of a pesticide on vertebrate populations, such models are very data-demanding and 
case studies are rare (see e.g. Watkinson et al. 2000). Systemic insecticides are known to affect invertebrate populations (e.g. Whitehorn et al. 2012; Van Dijk et al. 2013), but the lack of evidence for, and difficulty in determining, comparable indirect effects on vertebrates is an issue in ecotoxicology. There remains an essential need to determine if a causal link between loss of insect prey through pesticide use and the decline of vertebrate populations exists. This is especially true in North America and Europe where neonicotinoids are being used in large quantities and over vast areas.

\section{Conclusions}

Neonicotinoid and fipronil insecticides can exert their impact on vertebrates either directly, through their overt toxicity, or indirectly, for example, by reducing their food supply. Marked variation exists among taxa and different systemic insecticides in acute toxicity (as measured by $\mathrm{LD}_{50}$ and $\mathrm{LC}_{50}$ ), while a range of sub-lethal effects can occur at concentrations orders of magnitude below those causing lethality. Overall, at concentrations relevant to field exposure scenarios from seed treatments (birds) or water concentrations (fish), imidacloprid and clothianidin can be considered a risk to granivorous bird species, while fipronil may pose a similar risk to sensitive fish species. Except in the most extreme cases, however, concentrations of imidacloprid and clothianidin that fish and amphibians are exposed to appear to be substantially below thresholds to cause mortality, although sub-lethal effects have not been widely studied.

Despite the lack of research and the difficulty in assigning causation, indirect effects may be as - or even more-important than direct toxic effects on vertebrates, as modern systemic insecticides are more effective at killing the invertebrate prey of vertebrates than the vertebrates themselves. Given the data here, current risk assessment procedures for neonicotinoids and other systemic pesticides need to consider the associated risks from both direct and indirect effects to vertebrate wildlife.

Acknowledgments This manuscript benefited from discussions in the International Task Force on Systemic Pesticides (TFSP) during its plenary meetings in Paris (2010), Bath (2011), Cambridge (2012), Padua (2012), Louvain-la-Neuve (2013) and Legnaro (2013). We thank the members of the TFSP for their advice and encouragement, particularly Dominique Noome, Maarten Bijleveld van Lexmond, Jeroen van der Sluijs, Noa Simon Delso and Jean-Marc Bonmatin. We also thank Brigitte Poulin and Barnett Rattner for generously providing a critical review of an earlier version of the manuscript. The work of the TFSP was funded by Triodos Foundation's 'Support Fund for Independent Research on Bee Decline and Systemic Pesticides'. This Support Fund was created from donations by Adessium Foundation (The Netherlands), Act Beyond Trust (Japan), Universiteit Utrecht (Netherlands), Stichting Triodos Foundation (The Netherlands), Gesellschaft fuer Schmetterlingsschutz (Germany), M.A.O.C. Gravin van Bylandt Stichting (The Netherlands), Zukunft
Stiftung Landwirtschaft (Germany), Study Association Storm (Student Association Environmental Sciences Utrecht University) and citizens. The funders had no role in study design, data collection and analysis, decision to publish, or preparation of the manuscript, and none of the authors received funding from any of these sources. The authors declare no conflicts of interest.

Open Access This article is distributed under the terms of the Creative Commons Attribution License which permits any use, distribution, and reproduction in any medium, provided the original author(s) and the source are credited.

\section{References}

Abou-Donia MB, Goldstein LB, Bullman S, Tu T, Khan WA, Dechkovskaia AM, Abdel-Rahman AA (2008) Imidacloprid induces neurobehavioral deficits and increases expression of glial fibrillary acidic protein in the motor cortex and hippocampus in offspring rats following in utero exposure. J Toxicol Environ Health A 71:119-130

Anon (2012) Addendum 7 to the draft assessment report; confirmatory data; imidacloprid. EU Commission

Avery ML, Fischer DL, Primus TM (1997) Assessing the hazard to granivorous birds feeding on chemically treated seeds. Pestic Sci 49:362-366

Avery ML, Primus TM, Mihaich EM, Decker DG, Humphrey JS (1998) Consumption of fipronil-treated rice seed does not affect captive blackbirds. Pest Manag Sci 52:91-96

Badgujar PC, Jain SK, Singh A, Punia JS, Gupta RP, Chandratre GA (2013) Immunotoxic effects of imidacloprid following 28 days of oral exposure in BALB/c mice. Environ Toxicol Pharmacol 35:408418

Bal R, Türk G, Yılmaz Ö, Etem E, Kuloğlu T, Baydaș G, Naziroğlu M (2012) Effects of clothianidin exposure on sperm quality, testicular apoptosis and fatty acid composition in developing male rats. Cell Biol Toxicol 28:187-200

Bal R, Türk G, Tuzcu M, Yılmaz Ö, Kuloğlu T, Baydaș G, Naziroğlu M, Yener Z, Etem E, Tuzcu Z (2013) Effects of the neonicotinoid insecticide, clothianidin, on the reproductive organ system in adult male rats. Drug Chem Toxicol 36:421-429

Beauchamp WD, Koford RR, Nudds TD, Clark RG, Johnson DH (1996) Long-term declines in nest success of prairie ducks. J Wildl Manag 60:247-257

Beggel S, Werner I, Connon RE, Geist JP (2010) Sublethal toxicity of commercial insecticide formulations and their active ingredients to larval fathead minnow (Pimephales promelas). Sci Total Environ 408(16):3169-3175

Beggel S, Werner I, Connon RE, Geist JP (2012) Impacts of the phenylpyrazole insecticide fipronil on larval fish: time-series gene transcription responses in fathead minnow (Pimephales promelas) following short-term exposure. Sci Total Environ 426:160-165

Benton TG, Bryant DN, Cole L, Crick HQP (2002) Linking agricultural practice to insect and bird populations: a historical study over three decades. J Appl Ecol 39:673-687

Berny PJ, Buronfosse F, Videmann B, Buronfosse T (1999) Evaluation of the toxicity of imidacloprid in wild birds. A new high performance thin layer chromatography (HPTLC) method for the analysis of liver and crop samples in suspected poisoning cases. J Liq Chrom Rel Technol 22:1547-1559

Bhardwaj S, Srivastava MK, Kapoor U, Srivastava LP (2010) A 90 days oral toxicity of imidacloprid in female rats: morphological, 
biochemical and histopathological evaluations. Food Chem Toxicol 48:1185-1190

Boatman ND, Brickle NW, Hart JD, Milsom TP, Morris AJ, Murray AWA, Murray KA, Pobertson PA (2004) Evidence for the indirect effects of pesticides on farmland birds. Ibis 146:131-143

Bonmatin JM, Marchand PA, Charvet R, Moineau I, Bengsch ER, Colin ME (2005) Quantification of imidacloprid uptake in maize crops. J Agric Food Chem 53:5336-5341

Bradbury RB, Kyrkos A, Morris AJ, Clark SC, Perkins AJ, Wilson JD (2000) Habitat associations and breeding success of yellowhammers on lowland farmland. J Appl Ecol 37:789-805

Bradbury RB, Wilson JD, Moorcroft D, Morris A, Perkins AJ (2003) Habitat and weather are weak correlates of nestling condition and growth rates of four UK farmland passerines. Ibis 145:295-306

Brickle NW, Peach WJ (2004) The breeding ecology of Reed Buntings Emberiza schoeniclus in farmland and wetland habitats in lowland England. Ibis 146:69-77

Brickle NW, Harper DGC, Aebischer NJ, Cockayne SH (2000) Effects of agricultural intensification on the breeding success of corn buntings Miliaria calandra. J Appl Ecol 37:742-755

Britschgi A, Spaar R, Arlettaz R (2006) Impact of grassland farming intensification on the breeding ecology of an indicator insectivorous passerine, the Whinchat Saxicola rubetra: Lessons for overall Alpine meadowland management. Biol Conserv 130:193-205

Butler SJ, Mattison EHA, Glithero NJ, Robinson LJ, Atkinson PW, Gillings S, Vickery JA, Norris K (2010) Resource availability and the persistence of seed-eating bird populations in agricultural landscapes : a mechanistic modelling approach. J Appl Ecol 47:67-75

Callahan J, Mineau P (2008) Evaluation of clinical sign data from avian acute oral toxicity studies. Appendix 11; Scientific opinion of the panel on plant protection products and their residues on risk assessment for birds and mammals. EFSA J 734, 10pp

Casida JE, Durkin KA (2013) Neuroactive insecticides: targets, selectivity, resistance, and secondary effects. Annu Rev Entomol 58:99-117

Chamberlain DE, Fuller RJ, Bunce RGH, Duckworth JC, Shrubb M (2000) Changes in the abundance of farmland birds in relation to the timing of agricultural intensification in England and Wales. J Appl Ecol 37:771-788

Clasen B, Loro VL, Cattaneo R, Moraes B, Lópes T, de Avila LA, Zanella R, Reimche GB, Baldisserotto B (2012) Effects of the commercial formulation containing fipronil on the non-target organism Cyprinus carpio: Implications for rice-fish cultivation. Ecotoxicol Environ Saf 77:45-51

Connelly P (2011) Environmental fate of fipronil. Californian Environmental Protection Agency, Sacramento

Cowles RS, Montgomery ME, Cheah CAS-J (2006) Activity and residues of imidacloprid applied to soil and tree trunks to control Hemlock Wooly Adelgid (Hemiptera: Adelgidae) in Forests. J Econ Entomol 99:1258-1267

Cox C (2001) Insecticide factsheet: imidacloprid. J Pestic Reform 21:1521

Cutler GC, Scott-Dupree CD (2007) Exposure to clothianidin seedtreated canola has no long-term impact on honey bees. J Econ Entomol 100:765-772

de Leeuw J, Gorree M, de Snoo GR, Jamis WLM, van der Poll RJ, Luttik R (1995) Risks of granules of treated seeds to birds on arable fields. GML report no. 118. Centre of Environmental Science, Leiden University, Leiden, ISSN 1381-1703

de Oliveira IM, Nunes BV, Barbosa DR, Pallares AM, Faro LR (2010) Effects of the neonicotinoids thiamethoxam and clothianidin on in vivo dopamine release in rat striatum. Toxicol Lett 192:294-297

DeCant J, Barrett M (2010) Environmental fate and ecological risk assessment for the registration of clothianidin for use as a seed treatment on mustard seed (oilseed and condiment) and cotton. United States Environmental Protection Agency, Washington

Demsia G, Vlastos D, Goumenou M, Matthopoulos DP (2007) Assessment of the genotoxicity of imidacloprid and metalaxyl in cultured human lymphocytes and rat bone-marrow. Mutat Res 634: 32-39

Donald PF, Green RE, Heath MF (2001) Agricultural intensification and the collapse of Europe's farmland bird populations. Proc R Soc B 268:25-29

Donnarumma L, Pulcini P, Pochi D, Rosati S, Lusco L, Conte E (2011) Preliminary study of persistence in soil and residues in maize of imidacloprid. J Environ Sci Health B 46:469-472

Dunn JC, Hamer KC, Benton TG (2010) Fear for the family has negative consequences: indirect effects of nest predators on chick growth in a farmland bird. J Appl Ecol 47:994-1002

Duzguner V, Erdogan S (2012) Chronic exposure to imidacloprid induces inflammation and oxidative stress in the liver and central nervous system of rats. Pestic Biochem Physiol 104:58-64

European Commission (2005) Clothianidin. SANCO/10533/05-Final, $26 \mathrm{pp}$

Falcone JF, DeWald LE (2010) Comparisons of arthropod and avian assemblages in insecticide-treated and untreated eastern hemlock (Tsuga canadensis [L.] Carr) stands in Great Smoky Mountains National Park, USA. For Ecol Manag 260:856-863

Feng S, Kong Z, Wang X, Zhao L, Peng P (2004) Acute toxicity and genotoxicity of two novel pesticides on amphibian, Rana $N$ Hallowell. Chemosphere 56:457-463

Fossen M (2006) Environmental fate of imidacloprid. Department of Pesticide Regulation, Sacramento

Garthwaite DG, Thomas MR, Dawson A, Stoddart H (2003) Pesticide Usage Survey Report 187: arable crops in Great Britain 2002. Department for Environment, Food and Rural Affairs, London

Gawade L, Dadarkar SS, Husain R, Gatne M (2013) A detailed study of developmental immunotoxicity of imidacloprid in Wistar rats. Food Chem Toxicol 51:61-70

Ghilain A, Bélisle M (2008) Breeding success of tree swallows along a gradient of agricultural intensification. Ecol Appl 18:1140-1154

Ghisi D d C, Ramsdorf WA, Vinícius M, Ferraro M, Almeida MIM, Ribeiro CA d O, Cestari MM (2011) Evaluation of genotoxicity in Rhamdia quelen (Pisces, Siluriformes) after sub-chronic contamination with Fipronil. Environ Monit Assess 180:589-599

Gibbons DW, Bohan DA, Rothery P, Stuart RC, Haughton AJ, Scott RJ, Wilson JD, Perry JN, Clark SJ, Dawson RJG, Firbank L (2006) Weed seed resources for birds in fields with contrasting conventional and genetically modified herbicide-tolerant crops. Proc R Soc B 273:1921-1928

Gibbs KE, Mackey RL, Currie DJ (2009) Human land use, agriculture, pesticides and losses of imperiled species. Divers Distrib 15:242253

Golawski A, Meissner W (2008) The influence of territory characteristics and food supply on the breeding performance of the Red-backed Shrike (Lanius collurio) in an extensively farmed region of eastern Poland. Ecol Res 23:347-353

Goulson D (2013) An overview of the environmental risks posed by neonicotinoid insecticides. J Appl Ecol 50:977-987

Grant DB, Chalmers AE, Wolff MA, Hoffman HB, Bushey DF, Kuhr RJ, Motoyama N (1998) Fipronil: action at the GABA receptor. In: Kuhr RJ, Motoyama N (eds) Pesticides and the Future: minimizing chronic exposure of humans and the environment. IOS Press, Amsterdam, pp 147-156

Gu YH, Li Y, Huang XF, Zheng JF, Yang J, Diao H, Yuan Y, Xu Y, Liu M, Shi HJ, Xu WP (2013) Reproductive effects of two neonicotinoid insecticides on mouse sperm function and early embryonic development in vitro. PLoS ONE e70111

Hart JD, Milsom TP, Fisher G, Wilkins V, Moreby SJ, Murray AWA, Robertson PA (2006) The relationship between yellowhammer breeding performance, arthropod abundance and insecticide applications on arable farmland. J Appl Ecol 43:81-91

Hayasaka D, Korenaga T, Suzuki K, Saito F, Sanchez-Bayo F, Goka K (2012) Cumulative ecological impacts of two successive annual 
treatments of imidacloprid and fipronil on aquatic communities of paddy mesocosms. Ecotoxicol Environ Saf 80:355-362

Hillegass MA, Waterman JM, Roth JD (2010) Parasite removal increases reproductive success in a social African ground squirrel. Behav Ecol 21:696-700

Hole DG, Whittingham MJ, Bradbury RB, Anderson GQA, Lee PLM, Wilson JD, Krebs JR (2002) Widespread local house-sparrow extinctions. Nature 418:931-932

Howard JH, Julian SE, Ferrigan J (2003) Golf course maintenance: impact of pesticides on amphibians. Golf Course Mon, September 94-101

Hudson PJ, Newborn D, Dobson AP (1992) Regulation and stability of a free-living host-parasite system: Trichostrongylus tenuis in red grouse. 1. Monitoring and parasite reduction experiments. J Anim Ecol 61:477-486

Jemec A, Tišler T, Drobne D, Sepčic' K, Fournier D, Trebše P (2007) Comparative toxicity of imidacloprid, of its commercial liquid formulation and of diazinon to a non-target arthropod, the microcrustacean Daphnia magna. Chemosphere 68:1408-1418

Jeschke P, Nauen R (2008) Neonicotinoids - from zero to hero in insecticide chemistry. Pest Manag Sci 64:1084-1098

Jeschke P, Nauen R, Schindler M, Elbert A (2011) Overview of the status and global strategy for neonicotinoids. J Agric Food Chem 59:2897-2908

Johansson OC, Blomqvist D (1996) Habitat selection and diet of lapwing, Vanellus vanellus, chicks on coastal farmland in SW Sweden. J Appl Ecol 33:1030-1040

Kapoor U, Srivastava MK, Bhardwaj S, Srivastava LP (2010) Effect of imicacloprid on antioxidant enzymes and lipid peroxidation in female rats to derive its No Observed Effect Level (NOEL). J Toxicol Sci 35:577-581

Kaur B, Sandhu HS, Kaur R (2006) Toxic effects of subacute oral exposure of imidacloprid on biochemical parameters in crossbred cow calves. Toxicol Int 13:43-47

Kitulagodage M, Astheimer LB, Buttemer WA (2008) Diacetone alcohol, a dispersant solvent, contributes to acute toxicity of a fipronil-based insecticide in a passerine bird. Ecotoxicol Environ Saf 71:597-600

Kitulagodage M, Buttemer WA, Astheimer LB (2011a) Adverse effects of fipronil on avian reproduction and development: maternal transfer of fipronil to eggs in zebra finch Taeniopygia guttata and in ovo exposure in chickens Gallus domesticus. Ecotoxicol 20:653-660

Kitulagodage M, Isanhart J, Buttemer WA, Hooper MJ, Astheimer LB (2011b) Fipronil toxicity in northern bobwhite quail Colinus virginianus: reduced feeding behaviour and sulfone metabolite formation. Chemosphere 83:524-530

Köhler H-R, Triebskorn R (2013) Wildlife ecotoxicology of pesticides: can we track effects to the population level and beyond. Science 341:759 765

Kreuger J, Graaf S, Patring J, Adieslsson S (2010) Pesticides in surface water in areas with open ground and greenhouse horticultural crops in Sweden, 2008. Swedish University of Agricultural Science. http:// www-mv.slu.se/webfiles/vv/CKB/Ekohydrologi_117_ENG.pdf. Accessed 4 Feb 2013

Krupke CH, Hunt GJ, Eitzer BD, Andino G, Given K (2012) Multiple routes of pesticide exposure for honey bees living near agricultural fields. PLoS ONE 7:e29268. doi:10.1371/journal.pone.0029268

Lamers M, Anyusheva M, La N, Nguten V, Streck T (2011) Pesticide pollution in surface and groundwater by paddy rice cultivation: a case study from Northern Vietnam. Clean Soil Air Water 39:356-361

Lauan MCB, Ocampo PP (2013) Low-dose effects of carbaryl, chlorpyrifos and imidacloprid on the gonad and plasma testosterone level of male juvenile and adult Nile tilapia (Oreochromis niloticus Linnaeus). Asia Life Sci 1:239-250

Leghait J, Gayrard V, Toutain P-L, Picard-Hagen N, Viguié C (2010) Is the mechanism of fipronil-induced thyroid disruption specific to the rat: re-evaluation of fipronil thyroid toxicity in sheep? Toxicol Lett 194:351-357
Lopez-Antia A, Ortiz-Santaliestra ME, Mougeot F, Mateo R (2013) Experimental exposure of red-legged partridges (Alectoris rufa) to seeds coated with imidacloprid, thiram and difenoconazole. Ecotoxicol 22:125-138. doi:10.1007/s10646-012-1009-x

Main AR, Headley JV, Peru KM, Michel NL, Cessna AJ, Morrisey CA (2014) Widespread use and frequent detection of neonicotinoid insecticides in wetlands of Canada's Prairie Pothole Region. PLoS ONE 9:e92821

Martin PA, Johnson DL, Forsyth DJ, Hill BD (2000) Effects of two grasshopper control insecticides on food resources and reproductive success of two species of grassland songbirds. Environ Toxicol Chem 19:2987-2996

Martins AP (2009) Neurobehavioural effects of acute fipronil administration in rats. PhD thesis, Faculdade de Medicina Veterinária e Zootecnia, Universidade de São Paulo

Mason R, Tennekes H, Sánchez-Bayo F, Jepsen PU (2012) Immune suppression by neonicotinoid insecticides at the root of global wildlife declines. J Environ Immunol Toxicol 1:3-12

Mineau P (2005) A review and analysis of study endpoints relevant to the assessment of 'long term' pesticide toxicity in avian and mammalian wildlife. Ecotoxicol 14:775-799

Mineau P (2011) Barking up the wrong perch: why we should stop ignoring non-dietary routes of pesticide exposure in birds. Integr Environ Assess Manag 7:297-305

Mineau P, Palmer C (2013) The impact of the nation's most widely used insecticides on birds. American Bird Conservancy, USA

Mineau P, Whiteside M (2013) Pesticide acute toxicity is a better correlate of U.S. grassland bird declines than agricultural intensification. PLoS ONE 8:e57457

Mineau P, Boersma DC, Collins B (1994) An analysis of avian reproduction studies submitted for pesticide registration. Ecotoxicol Environ Saf 29:304-329

Mineau P, Balcomb R, Bennett R, Dobson S, Fry M, Jaber M, Leopold A, Munk R, Ringer B, Rispin A, Sileo L, Solecki R, Thompson H (1996) Testing for effects on reproduction. In: Report of the SETAC/OECD Workshop on Avian Toxicity Testing. Inter-Organizational Programme for the Sound Management of Chemicals, OECD Environmental Health and Safety Publications, Series on Testing and Assessment No. 5 , pp 44-62

Mineau P, Fletcher MR, Glaser LC, Thomas NJ, Brassard C, Wilson LC, Elliott JE, Lyon LA, Henny CJ, Bollinger T, Porter SL (1999) Poisoning of raptors with organophosphorous and carbamate pesticides with emphasis on Canada, the United States and the United Kingdom. J Raptor Res 33:1-37

Mize SV, Porter SD, Demcheck DK (2008) Influence of fipronil compounds and rice cultivation land-use intensity on macro-invertebrate communities in streams of southwestern Louisiana, USA. Environ Pollut 152:491-503

Mohany M, Badr G, Refaat I, El-Feki M (2011) Immunological and histological effects of exposure to imidacloprid insecticide in male albino rats. Afr J Pharm Pharmacol 5:2106-2114

Moller AP (2001) The effect of dairy farming on barn swallow Hirundo rustica abundance, distribution and reproduction. J Appl Ecol 38: 378-389

Morris AJ, Wilson JD, Whittingham MJ, Bradbury RB (2005) Indirect effects of pesticides on breeding yellowhammer (Emberiza citrinella). Agric Ecosyst Environ 106:1-16

Nagy LR, Holmes RT (2004) Factors influencing fecundity in migratory songbirds: is nest predation the most important? J Avian Biol 35: $487-491$

Nagy LR, Holmes RT (2005) Food limits annual fecundity of a migratory songbird: an experimental study. Ecol 86:675-681

Nellore K, Raj K, Usha Rani CT, Jacob DP (2010) Studies on the effect of imidacloprid toxicity on the acetylcholine esterase activity levels in different regions of the brain of the albino rat. Int J Agric Environ Biotechnol 3:377-380 
Newton I (1995) The contribution of some recent research on birds to ecological understanding. J Anim Ecol 64:675-695

Nian Y (2009) Study on toxicity of triazophos, trichlorphon and imidacloprid on Rana limnocharis tadpole. J Anhui Agric Sci 2009:18

Norelius EE, Lockwood JA (1999) The effects of reduced agent-area insecticide treatments for rangeland grasshopper (Orthoptera: Acrididae) control on bird densities. Arch Environ Contam Toxicol 37:519-528

Ocampo PP, Sagun VG (2007) Gonadal changes in male tilapia (Oreochromis niloticus Linn.) after exposure to imidacloprid insecticide. Phillipine Entomol 21:199-200

Ohi M, Dalsenter PR, Andrade AJM, Nascimento AJ (2004) Reproductive adverse effects of fipronil in Wistar rats. Toxicol Lett 146:121-127

Pascual JA, Hart ADM, Saunders PJ, McKay HV, Kilpatrick J, Prosser P (1999) Agricultural methods to reduce the risk to birds from cereal seed treatments on fenlands in eastern England. I. Sowing depth. Agric Ecosyst Environ 72:59-73

Peveling R, Demba SA (2003) Toxicity and pathogenicity of Metarhizium anisopliae var. acridum (Deuteromycotina, Hyphomycetes) and fipronil to the fringe-toed lizard Acanthodactylus dumerili (Squamata: Lacertidae). Environ Toxicol Chem 22:1437-1447

Peveling R, McWilliam AN, Nagel P, Rasolomanana H, Raholijaona, Rakotomianina L, Ravoninjatovo A, Dewhurst CF, Gibson G, Rafanomezana S, Tingle CCD (2003) Impact of locust control on harvester termites and endemic vertebrate predators in Madagascar. J Appl Ecol 40:729-741

Potts GR (1986) The partridge - pesticides, predation and conservation. Collins, London

Poulin B, Lefebvre G, Paz L (2010) Red flag for green spray: adverse trophic effects of Bti on breeding birds. J Appl Ecol 47:884-889

Prosser P, Hart ADM (2005) Assessing potential exposure of birds to pesticide-treated seeds. Ecotoxicol 14:679-691

Rands MRW (1985) Pesticide use on cereals and the survival of grey partridge chicks: a field experiment. J Appl Ecol 22:49-54

Ratcliffe DA (1967) Decrease in eggshell weight in certain birds of prey. Nature 215:208-210

Robillard A, Garant D, Bélisle M (2013) The swallow and the sparrow: how agricultural intensification affects abundance, nest site selection and competitive interactions. Landsc Ecol 28:201-215

Rouchaud J, Gustin F, Wauters A (1994) Soil biodegradation and leaf transfer of insecticide imidacloprid applied in seed dressing in sugar beet crops. Bull Environ Contam Toxicol 53:344-350

Sánchez-Bayo F (2011) Impacts of agricultural pesticides on terrestrial ecosystems. In: Sánchez-Bayo F (ed) Ecological impacts of toxic chemicals. Bentham Science Publishers Ltd, USA, pp 63-87

Sánchez-Bayo F, Goka K (2005) Unexpected effects of zinc pyrithione and imidacloprid on Japanese medaka fish (Oryzias latipes). Aquat Toxicol 74:285-293

Selås V, Steen R, Kobro S, Lislevand T, Stenberg I (2008) Direct and indirect weather impacts on spring populations of lesser spotted woodpecker (Dendrocopos minor) in Norway. Scand J For Res 23:148-153

SERA (2005) Imidacloprid - human health and ecological risk assessment-final report. Report from Syracuse Environmental Research Associates to USDA, Forest Service

Simons LS, Martin TE (1990) Food limitation of avian reproduction: an experiment with the Cactus Wren. Ecol 71:869-876

Siriwardena GM, Ballie SR, Crick HQP, Wilson JD (2000) The importance of variation in the breeding performance of seed-eating birds in determining their population trends on farmland. J Appl Ecol 37: $128-148$

Sotherton N, Holland J (2002) Indirect effects of pesticides on farmland wildlife. In: Hoffman DJ, Rattner BA, Allen Burton G, Cairns J (eds) Handbook of ecotoxicology, 2nd edn. CRC Press Ltd, USA, pp 1173-1196
Stark JD, Vargas RI (2005) Toxicity and hazard assessment of fipronil to Daphnia Pulex. Ecotoxicol Environ Saf 62:11-16

Starner K, Goh KS (2012) Detections of the neonicotinoid insecticide imidacloprid in surface waters of three agricultural regions of California, USA, 2010-2011. Bull Environ Contam Toxicol 88: 316-321

Stehr CM, Linbo TL, Incardona JP, Scholz NL (2006) The developmental neurotoxicity of fipronil: notochord degeneration and locomotor defects in zebrafish embryos and larvae. Toxicol Sci 92:270-278

Stoughton SJ, Liber K, Culp J, Cessna A (2008) Acute and chronic toxicity of imidacloprid to the aquatic invertebrates Chironomus tentans and Hyalella azteca under constant- and pulse-exposure conditions. Archives Environ Contam Toxicol 54:662-673

Suryanarayanan S (2013) Balancing control and complexity in field studies of neonicotinoids and honey bee health. Insects 4:153-167

Tanaka T (2012) Reproductive and neurobehavioral effects of clothianidin administered to mice in the diet. Birth Defects Res B 95:151-159. doi:10.1002/bdrb.20349

Tennekes H (2010) The systemic insecticides: a disaster in the making. ETS Nederland BV, Zutphen, The Netherlands

Terçariol PRG, Godinho AF (2011) Behavioural effects of acute exposure to the insecticide fipronil. Pestic Biochem Physiol 99:221-225

Tingle CCD, Rother JA, Dewhurst CF, Lauer S, King WJ (2000) Health and environmental effects of fipronil. Briefing paper for Pesticides Action Network, UK

Tingle CCD, Rother JA, Dewhurst CF, Lauer S, King WJ (2003) Fipronil: environmental fate, ecotoxicology and human health concerns. Rev Environ Contam Toxicol 176:1-66

Tišler T, Jemec A, Mozetič B, Trebše P (2009) Hazard identification of imidacloprid to aquatic environment. Chemosphere 76:907-914

Tokumoto J, Danjo M, Kobayashi Y, Kinoshita K, Omotehara T, Tatsumi A, Hashiguchi M, Sekijima T, Kamisoyama H, Yokoyama T, Kitagawa H, Hoshi N (2013) Effects of exposure to clothianidin on the reproductive system of male quails. J Vet Med Sci 75:755-760

Tomizawa M, Casida JE (2005) Neonicotinoid insecticide toxicology: mechanisms of selective action. Annu Rev Pharmacol Toxicol 45: 247-268

Tomizawa M, Casida JF (2011) Neonicotinoid insecticides: highlights of a Symposium on Strategic Molecular Designs. J Agric Food Chem 59:2883-2886

Toor HK, Sangha GK, Khera KS (2013) Imidacloprid induced histological and biochemical alterations in liver of female albino rats. Pestic Biochem Physiol 105:1-4

US EPA (2008) Imidacloprid summary document registration review: initial docket December 2008. Docket Number: EPA-HQ-OPP2008-0844

US EPA (2012) United States Environmental Protection Agency Ecological Risk Assessment. http://www.epa.gov/oppefed1/ ecorisk ders/toera analysis eco.htm. Accessed 27 Oct 2012

Van Dijk T, Van Staalduinen MĀ, Van der Sluijs JP (2013) Macroinvertebrate decline in surface water polluted with imidacloprid. PLOS ONE 8:e62374. doi:10.1371/journal.pone.0062374

Watkinson AR, Freckleton RP, Robinson RA, Sutherland WJ (2000) Predictions of biodiversity response to genetically modifed herbicide-tolerant crops. Science 289:1554-1557

Whitehorn PR, O'Connor S, Wackers FL, Goulson D (2012) Neonicotinoid pesticide reduces bumble bee colony growth and queen production. Science 336:351-352

Wirth EF, Pennington PL, Lawton JC, DeLorenzo ME, Bearden D, Shaddrix B, Sivertsen S, Fulton MH (2004) The effects of the contemporary-use insecticide Firponil in an estuarine mesocosm. Environ Pollut 131:365-371

Zanette L, Clinchy M, Smith JNM (2006) Combined food and predator effects on songbird nest survival and annual reproductive success: results from a bi-factorial experiment. Oecol 147:632-640 